\title{
The Mighty Walser: From a Short Story by Robert Walser, a Choreographer and Director Have Made a Mesmerizing Piece of "Perambulatory Poetics."
}

Sukhdev Sandhu, New York University

Keywords: Robert Walser, All This Can Happen, Siobhan Davies, David Hinton, perambulatory poetics, archive film, split-screen, review

Ed. note: This review is a reprint, originally published in BFl's international film magazine, Sight\&Sound in December 2013. ${ }^{1}$

By Christmas Day 1956, when his frozen body was found by schoolchildren in a field of snow near the asylum where he had resided for more than twenty years, the Swiss writer Robert Walser had been largely forgotten. There had been a time when the failed actor and former butler, born in 1878, was well known among Europe's literary intelligentsia: Robert Musil, Herman Hesse, Stefan Zweig, Franz Kafka, and Walter Benjamin all admired his short stories and novels. During the 1920s, though, he was increasingly afflicted by hallucinations. In 1933 he entered a sanatorium, announcing: "I am not here to write, but to be mad."2

Since his death, Walser has attracted a new an equally ardent following. Susan Sontag, J.M. Coetzee, and W.G. Sebald have all been compelled by the vagrant, almost bathetic trajectory of his life, the mysteriously self-erasing qualities of his prose (which, according to Sebald, "has the tendency to dissolve upon reading, so that only a few hours later one can barely remember the ephemeral figures, events, and things of which it spoke") ${ }^{3}$, and the mesmerizing isolationism his writings project (his Microscripts, originally assumed to be written in a secret code and composed on tiny strips of paper, were so small that a whole story could fit on the back of a business card).

Now The Walk, a 1917 novella, has become the basis of All This Can Happen, a remarkable filmic treatment by Siobhan Davies and David Hinton. Its storyline is simple: a writer decides to go for a walk through a provincial Swiss town one morning and along the way encounters a bookseller who proffers him an acclaimed bestseller that he loathes, a bank official who gives him a large sum of money, a former actress, a giant who forces him to eat a huge lunch that leaves him in pain, and a tailor whom he berates.

The International Journal of Screendance 7 (2016). 
Who is this writer? He constantly refers to his modest means and frugal habits, but wears a dandyish yellow suit. By turns, he likens himself to a vagabond or vagrant, but also to a great lord or marquis, while coming across as a pompous Pooter type too. On his walk he displays a notary's or actuary's eye for detail, rendering his prose almost indexical, yet his language can be florid to the point of baroque. The landscapes through which he moves come across as stage sets, memory prompts, launch pads for pontifical disquisitions. The line between past and present, self and others, reality and unreality becomes blurry. At one point he even labels the walk "a fantasy."

All This Can Happen is a particularly bold example of perambulatory poetics that is, in different ways, informed by Rebecca Solnit's study Wanderlust (in which she celebrates walking for its ability to unite the heart and the head, emotional and analytical intelligence) and by the writings of Sebald-more than once, its haunted topographics and dense language recall Grant Gee's 2011 visual essay Patience (After Sebald).

It might be expected that Davies, a distinguished choreographer, and Hinton, a BAFTA winning director who has often been drawn to the work of dancers in his films, might be attracted to a fiction in which walking becomes an elaborate and idiosyncratic dance of thoughts and bodily gestures. What's striking is the emphasis they place on stasis, hesitancy, immobility: they incorporate often upsetting medical footage of men-presumably World War I veterans-trying to stand on their feet, hinting not only at the traumas Walser may have undergone during his own military service, but also at modernism's systematic preoccupation with breakdown and incapacity.

All This Can Happen is equally arresting as an archive film constructed entirely out of late-19th and early-20th-century home movies, natural history footage, and the pioneering photography of Étienne-Jules Marey. Streetscapes recall the accelerated poetry of 1920s city symphony films. Shots of office workers' body parts or mechanized labor evoke classic time-motion studies and European art's inter-war obsession with processes of atomization and psychological fragmentation.

Much of the film's movement is generated by the splitting of screens: a triptych of a man in various stages of washing resembles the slurred paroxysms of a Francis Bacon painting. At times there are fifteen images on screen, edited and arranged with a precision both forensic and intimate, all speaking-however tangentially-to each other. It's easy to imagine the work being presented in an art gallery, but Davies and Hinton's conceptual rigor, imaginative reach-to say nothing of the intricacy and subtlety with which they trace resonances between images-makes most art world split screen work seem gauche.

All This Can Happen could also function independently as an audio essay. Chu-Li Shewring's sound design creates a molecular illbience whose potency grows and grows. John Hefferman's voiceover is by turns droll, absurd, plaintive, stricken. Davies 
and Hinton have achieved the near-impossible: a film both harrowing and full of levity, pathological and poignant, microscopic and expansive. They have not so much captured as liberated Walser's unclassifiable genius.

\section{Biography}

Sukhdev Sandhu is Associate Professor of English Literature at New York University where he also directs the Colloquim for Unpopular Culture. His books include I'll Get My Coat (2005), Night Haunts: A Journey Through The London Night (2007) and Other Musics (2016). He is an award-winning film writer whose work appears in The Guardian, The Financial Times, Sight and Sound, The Wire and Bidoun.

Email: sukhdev.sandhu@nyu.edu

\section{Notes}

1 Sandhu, "The Mighty Walser."

${ }^{2}$ Middleton, introduction, 12.

${ }^{3}$ Sebald, A Place in the Country, 122.

${ }^{4}$ Walser, The Walk and Other Stories, 68.

\section{References}

All This Can Happen. Dir. Siobhan Davies and David Hinton. UK, 2012. Film.

Middleton, Christopher. Introduction to Jakob von Gunten: A Novel, by Robert Walser.

Trans. C. Middleton, 5-17. Austin/London: University of Texas Press, 1969. 5-17.

Patience (After Sebald). Dir. Grant Gee. UK, 2012. Film.

Sebald, W.G. A Place in the Country: On Gottfried Keller, Johann Peter Hebel, Robert Walser, and Others. Trans. J. Catling. London: Hamish Hamilton, 2013.

Solnit, Rebecca. Wanderlust: A History of Walking. London: Penguin Books, 2001. 
Sandhu, Sukhdev. "The Mighty Walser: From a Short Story by Robert Walser, a Choreographer and Director Have Made a Mesmerizing Piece of 'Perambulatory Poetics.'" Sight\&Sound, (Dec 2013): 56.

Walser, Robert. Microscripts. Trans. S. Bernofsky, New York: New Directions Publishing Corporation, 2010.

Walser, Robert. The Walk and Other Stories. Trans. C. Middleton and others, London: Serpent's Tail, 2013. 